\section{ENVIRONMENTAL MANAGEMENT \& ENRIGHMENT FACIITIES}

RECEIVED

JUN 151998

OSTI

\author{
Contingency Plan \\ for the Old Hydrofracture \\ Facility Tanks Sluicing Project \\ at Oak Ridge National Laboratory, \\ Oak Ridge, Tennessee
}

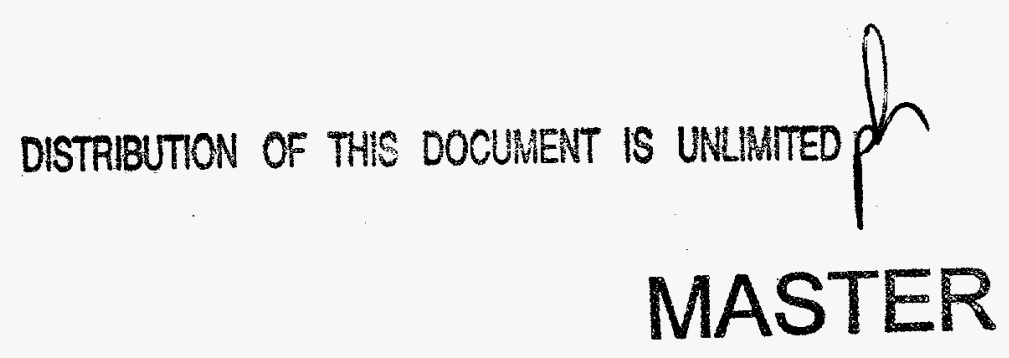

\title{
UNCONTROLLED COPY
}

This document has been approved

for release to the public. Date: 06/04/98 


\section{CDM Federal Programs Corporation}

contributed to the preparation of this document and should not be considered an eligible contractor for its review. 


\title{
Contingency Plan for the Old Hydrofracture Facility Tanks Sluicing Project at Oak Ridge National Laboratory, Oak Ridge, Tennessee
}

Date Issued-June 1998

\author{
Prepared by \\ CDM Federal Programs Corporation \\ Oak Ridge, Tennessee 37830 \\ under contract 96B-99052C \\ Document Control No. 5151-005-FR-BCBG \\ Prepared for the \\ U.S. Department of Energy \\ Office of Environmental Management \\ Environmental Management Activities at the \\ OAK RIDGE NATIONAL LABORATORY \\ Oak Ridge, Tennessee 37831 \\ managed by \\ BECHTEL JACOBS COMPANY LLC \\ for the \\ U.S. DEPARTMENT OF ENERGY \\ under contract DE-AC05-98OR22700
}




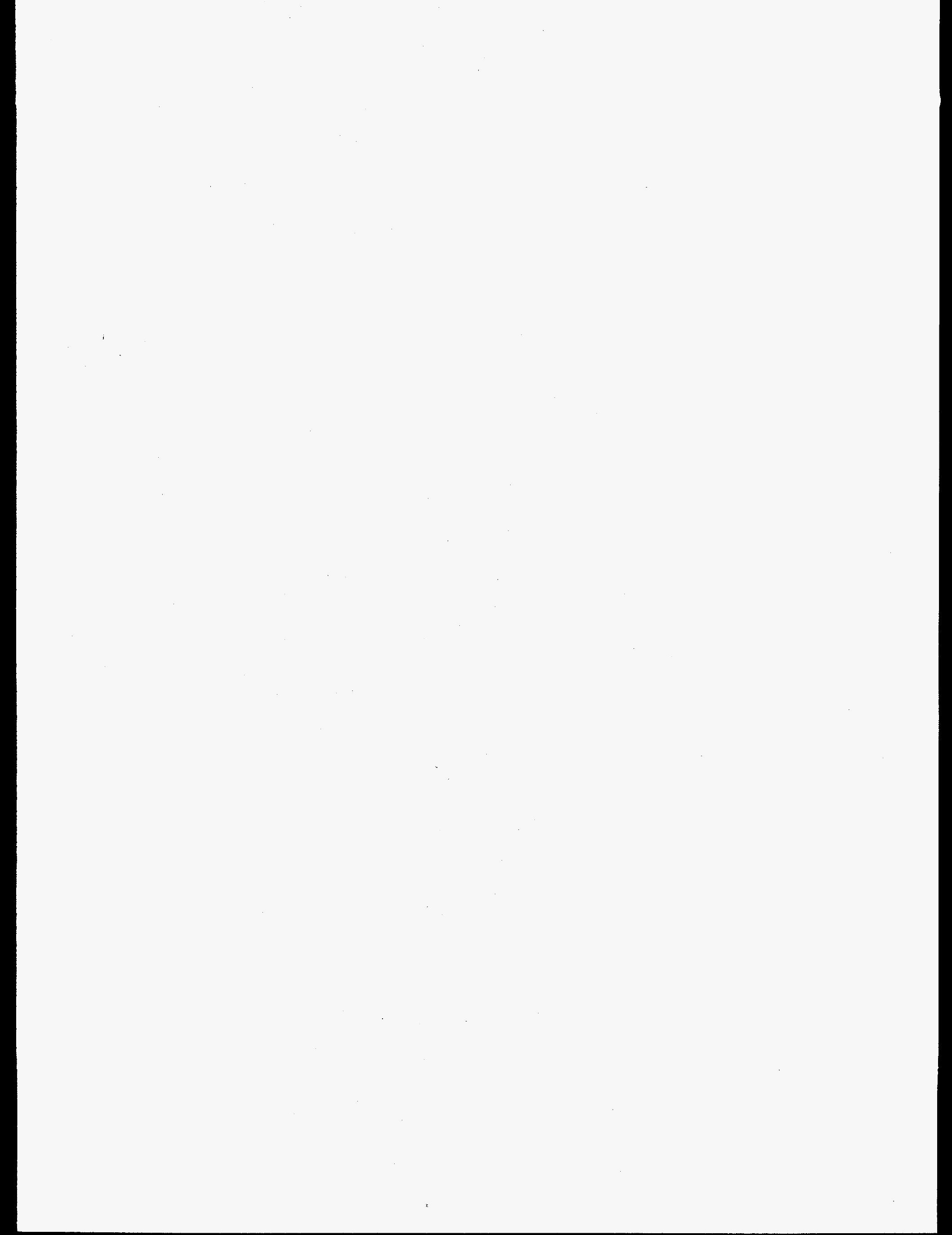




\section{DISCLAIMER}

This report was prepared as an account of work sponsored by an agency of the United States Government. Neither the United States Government nor any agency thereof, nor any of their employees, makes any warranty, express or implied, or assumes any legal liability or responsibility for the accuracy, completeness, or usefulness of any information, apparatus, product, or process disclosed, or represents that its use would not infringe privately owned rights. Reference herein to any specific commercial product, process, or service by trade name, trademark, manufacturez, or otherwise does not necessarily constitute or imply its endorsement, recommendation, or favoring by the United States Government or any agency thereof. The views and opinions of authors expressed herein do not necessarily state or reflect those of the United States Government or any agency thereof. 


\section{DISCLAIMER}

Portions of this document may be illegible electronic image products. Images are produced from the best available original document. 


\section{PREFACE}

This revision to the Contingency Plan for the Old Hydrofracture Facility (OHF) Tanks Sluicing Project at the Oak Ridge National Laboratory was prepared as a part of the OHF Tanks Contents Removal Project being conducted under the Comprehensive Environmental Response, Compensation, and Liability Act. This document outlines plans for preventing, detecting, and responding to potential release scenarios during the planned removal action. This document was originally released as document number ORNL/ER-383. 


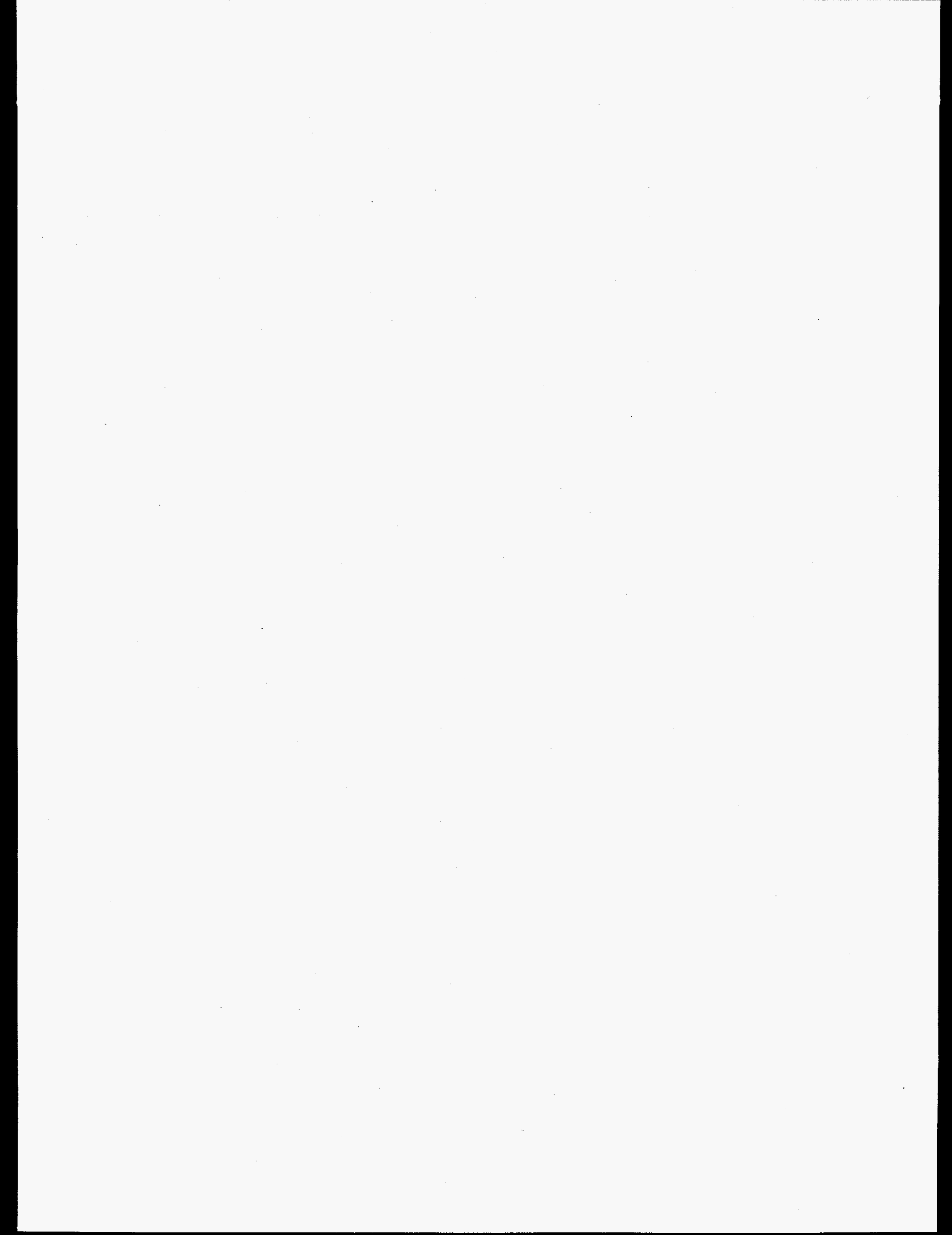




\section{CONTENTS}

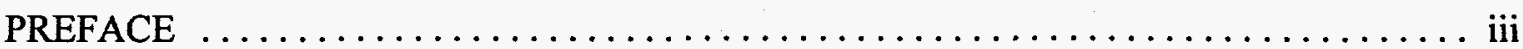

FIGURES $\ldots \ldots \ldots \ldots \ldots \ldots \ldots \ldots \ldots \ldots \ldots \ldots \ldots \ldots \ldots \ldots \ldots \ldots \ldots \ldots$ vii

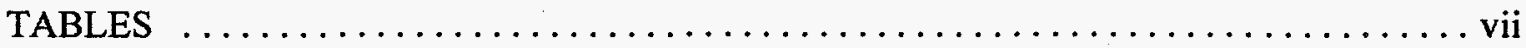

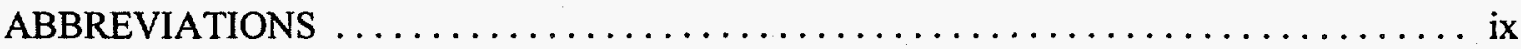

EXECUTIVE SUMMARY $\ldots \ldots \ldots \ldots \ldots \ldots \ldots \ldots \ldots \ldots \ldots \ldots \ldots \ldots \ldots \ldots \ldots \ldots \ldots$

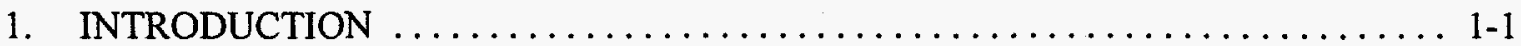

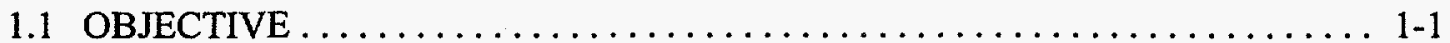

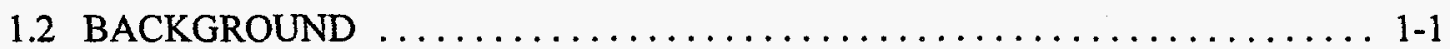

2. SITE DESCRIPTION AND ENVIRONMENTAL SETTING $\ldots \ldots \ldots \ldots \ldots \ldots \ldots$.

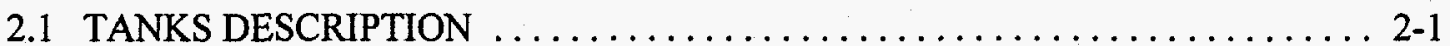

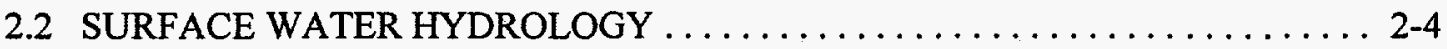

2.3 GROUNDWATER HYDROLOGY $\ldots \ldots \ldots \ldots \ldots \ldots \ldots \ldots \ldots \ldots \ldots \ldots \ldots \ldots \ldots$

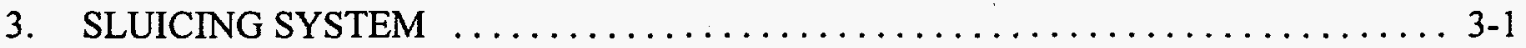

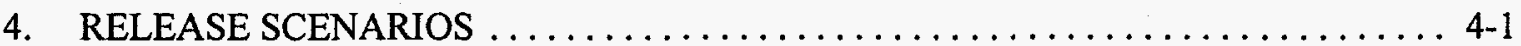

4.1 OVERVIEW OF RELEASE SCENARIOS $\ldots \ldots \ldots \ldots \ldots \ldots \ldots \ldots \ldots \ldots \ldots \ldots \ldots \ldots$

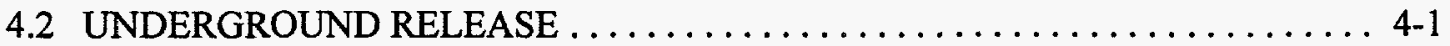

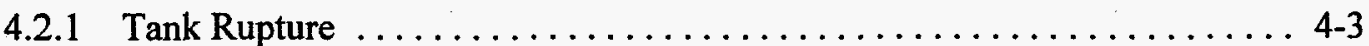

4.2 .2 Tank Leak ............................... 4.3

4.3 ABOVEGROUND LIQUID RELEASE $\ldots \ldots \ldots \ldots \ldots \ldots \ldots \ldots \ldots \ldots \ldots \ldots \ldots$

4.3.1 Waste Transfer Pipeline Rupture or Leak ... . . . . . . . . . . . 4-4

4.3.2 Leak from Operating Sluice Equipment ................ 4-4

4.3.3 Spill from Sluice Equipment During Maintenance or Transfer

Between Tanks ............................. $4-4$

4.4 VENTILATION SYSTEM FAILURE $\ldots \ldots \ldots \ldots \ldots \ldots \ldots \ldots \ldots \ldots \ldots \ldots \ldots \ldots \ldots$

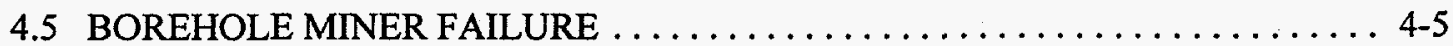

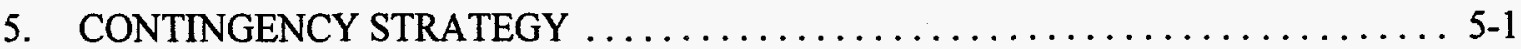

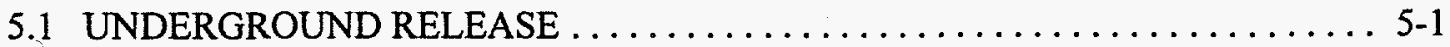

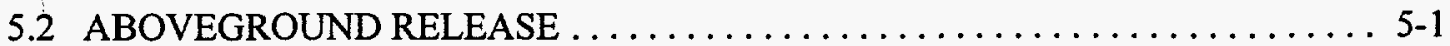

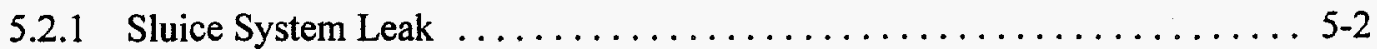

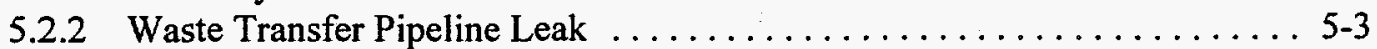

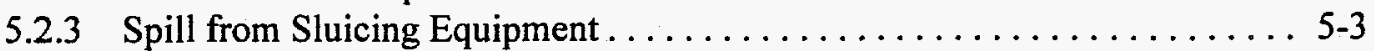

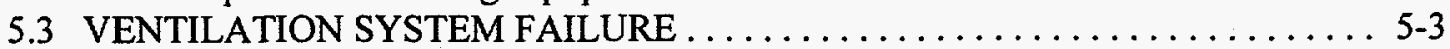


5.4 BOREHOLE MINER FAILURE $\ldots \ldots \ldots \ldots \ldots \ldots \ldots \ldots \ldots \ldots \ldots \ldots \ldots$. $5 . \ldots \ldots \ldots \ldots \ldots$

5.4.1 Management of the Borehole Miner Hose $\ldots \ldots \ldots \ldots \ldots \ldots \ldots \ldots . \ldots \ldots$

5.4 .2 Contingency Plan for the Borehole Miner ............... 5 5.4

5.5 REPORTING REQUIREMENTS $\ldots \ldots \ldots \ldots \ldots \ldots \ldots \ldots \ldots \ldots \ldots \ldots \ldots \ldots \ldots \ldots \ldots$

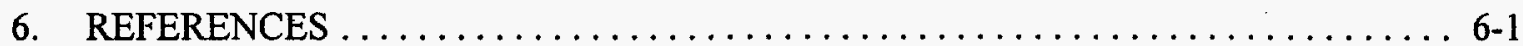




\section{FIGURES}

2.1 ORNL map showing OHF location.

2.2 Old Hydrofracture Facility site layout map

2.3 OHF tanks dry well system - plan view...

2.4 Vertical section showing OHF tanks backfill

2.5 Drainage system details for tanks $\mathrm{T}-1, \mathrm{~T}-2$, and $\mathrm{T}-9$

2.6 Drainage system details for tanks $\mathrm{T}-3$ and $\mathrm{T}-4$

2.7 Surface drainage at OHF tanks.

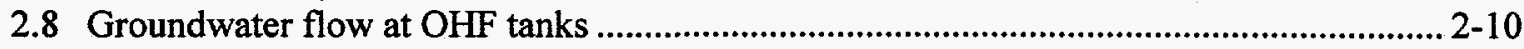

3.1 Process Flow Diagram, Oak Ridge National Laboratory, Old Hydrofracture Tank Contents Removal Project.

\section{TABLES}

2.1 Current tank contents. $2-1$

3.1 Tank contents and supernatant requirements

4.1 Sluicing project release scenario matrix

5.1 Contingency matrix 



\section{ABBREVIATIONS}

$\begin{array}{ll}\text { CDM Federal } & \text { CDM Federal Programs Corporation } \\ \text { DOE } & \text { U.S. Department of Energy } \\ \text { DOP } & \text { dioctyl phthalate } \\ \text { Energy Systems } & \begin{array}{l}\text { Lockheed Martin Energy Systems, Inc. } \\ \text { high-efficiency particulate air }\end{array} \\ \text { HEPA } & \text { liquid low-level waste } \\ \text { LLLW } & \text { Melton Valley Storage Tanks } \\ \text { MVST } & \text { Old Hydrofracture Facility } \\ \text { OHF } & \text { Oak Ridge National Laboratory } \\ \text { ORNL } & \text { Nuclear Criticality Safety Approval } \\ \text { NCSA } & \text { programmable logic controller } \\ \text { PLC } & \text { Waste Area Grouping } \\ \text { WAG } & \end{array}$




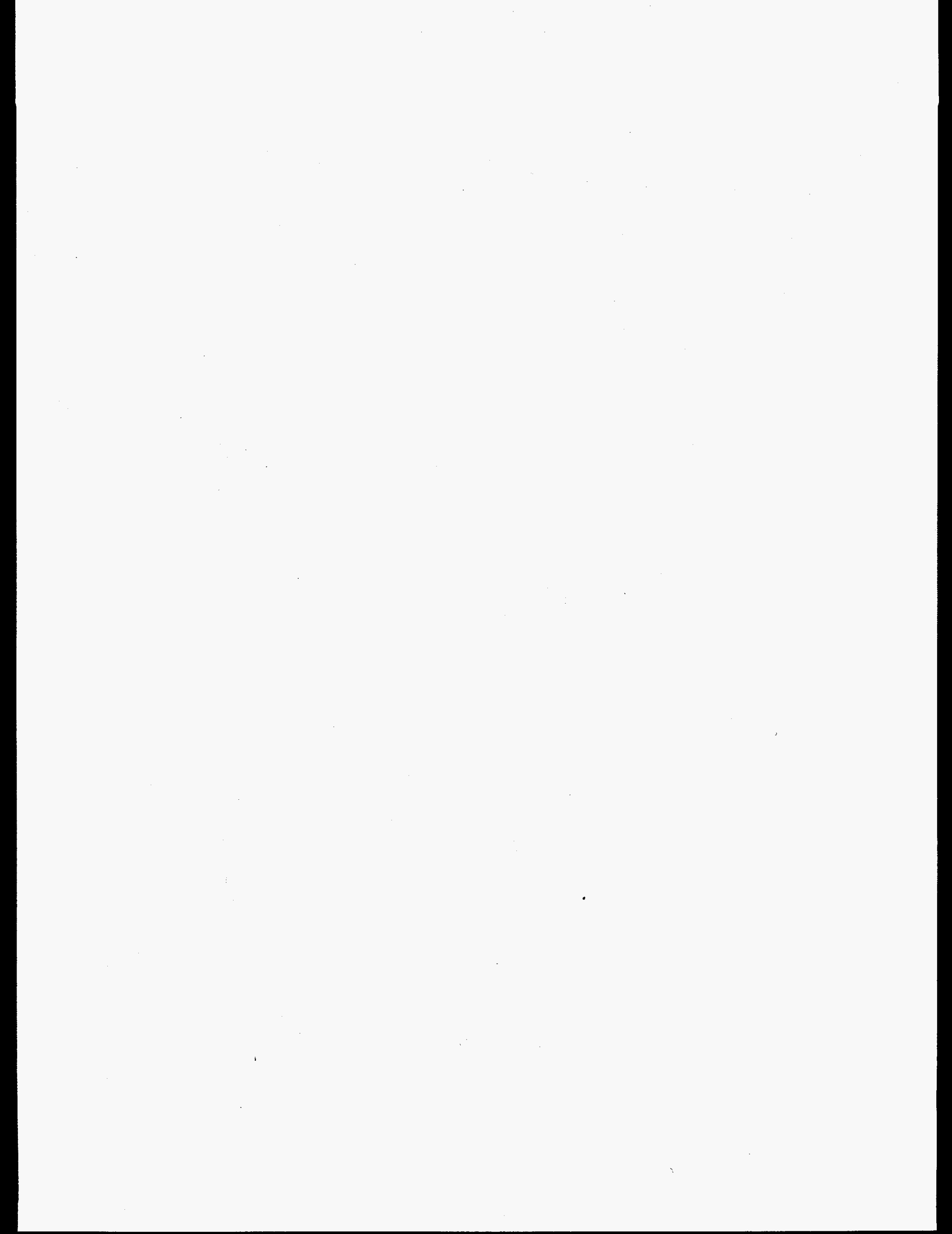




\section{EXECUTIVE SUMMARY}

This revised contingency plan addresses potential scenarios involving the release of radioactively contaminated waste from the Old Hydrofracture Facility Tanks Contents Removal project to the environment. The tanks are located at the Oak Ridge National Laboratory. The project involves sluicing the contents of the five underground tanks to mix the sludge and supernatant layers, and pumping the mixture to the Melton Valley Storage Tanks (MVST) for future processing. The sluicing system to be used for the project consists of a spray nozzle designated the "Borehole Miner," with an associated pump; in-tank submersible pumps to transfer tank contents from the sluice tanks to the recycle tank; high-pressure pumps providing slurry circulation and slurry transport to the MVST; piping; a ventilation system; a process water system; an instrumentation and control system centered around a programmable logic controller; a video monitoring system; and auxiliary equipment.

The earlier version of this plan, which was developed during the preliminary design phase of the project, identified eight scenarios in which waste from the tanks might be released to the environment as a result of unanticipated equipment failure or an accident (e.g., vehicular accident). One of those scenarios, nuclear criticality, is no longer addressed by this plan because the tank waste will be isotopically diluted before sluicing begins. The other seven scenarios have been combined into three, and a fourth, Borehole Miner Failure, has been added as follows:

- underground release from the tanks;

- aboveground release or spill from the sluicing system, a tank riser, or the transfer pipeline;

- release of unfiltered air through the ventilation system; and

- Borehole Miner arm retraction failure.

Methods for preventing, detecting, and responding to each release scenario are set out in the plan. The project has been designed with features to protect against environmental release, including the use of doubly contained pipelines; automatic pump cutoff systems; a backup generator for the instrumentation and control system; leak collection systems, and video camera monitoring of sluicing operations. Critical operating parameters of the sluicing system are monitored and alarmed, allowing for detection of a release or the conditions leading to a release. The plan also identifies responses that should be made by project personnel in the event of an environmental release. 


\section{INTRODUCTION}

The Old Hydrofracture Facility (OHF), located within Waste Area Grouping (WAG) 5 at the Oak Ridge National Laboratory (ORNL), includes five underground storage tanks that have been inactive since 1980 . The five tanks contain approximately 52,600 gal of liquid low-level waste (LLLW), consisting of approximately 43,100 gal of liquid and approximately 9,500 gal of sludge. On the basis of sampling projects carried out in 1988, 1995-96, and 1996-97, the tank contents have been characterized as mixed and transuranic waste. The radioactivity exhibited by the contents of the five tanks combined is approximately $29,500 \mathrm{Ci}$, most of which is contained within the sludge.

CDM Federal Programs Corporation (CDM Federal), under subcontract to the U.S. Department of Energy (DOE), is preparing to transfer the OHF tanks contents to the Melton Valley Storage Tanks (MVST), which are part of the active ORNL LLLW system. The tank contents will be sluiced to mix the sludge and supernatant into a slurry that will be pumped to MVST. The sluicing and pumping system - consisting of pumps, piping, a spray nozzle, a ventilation system, and auxiliary equipment - has been thoroughly tested at the ORNL Robotics and Process Systems Complex and will be reassembled at the OHF site. The system configuration is described in the Oak Ridge National Laboratory, Old Hydrofracture Facility Tanks Contents Removal Project 100\% Configuration (CDM Federal 1997). It will be operated as described in the Old Hydrofracture Facility Tanks Contents Removal Action Operations Plan at the Oak Ridge National Laboratory, Oak Ridge, Tennessee (Bechtel Jacobs Company LLC 1998). Safety and health requirements are detailed in the Site-Specific Health and Safety Plan for the Old Hydrofracture Facility Tanks Contents Removal Project at Oak Ridge National Laboratory, Oak Ridge, Tennessee (Energy Systems 1997).

\subsection{OBJECTIVE}

The objective of this contingency plan is to discuss possible scenarios in which the radioactively contaminated contents of the OHF tanks might be released to the environment during the sluicing and pumping process and to describe methods of preventing, detecting, and responding to any such release.

\subsection{BACKGROUND}

The OHF was built in 1963 to dispose of liquid waste by mixing it with grout and injecting it into a shale formation located approximately $1,000 \mathrm{ft}$ below ground surface. The five underground tanks were used to temporarily store liquid waste before mixing and injection. In addition to the five tanks considered in this report, the OHF includes Buildings 7852 and 7853, a pump house, storage silos, waste pits, a retention pond, and various support equipment and apparatus. The facility began operation in 1964 and was shut down in 1980. Since that time it has been maintained in a safe storage mode. Additional information regarding facility operation is included in the Site Characterization Summary Report for the Old Hydrofracture Facility, Waste Area Grouping 5, at Oak Ridge National Laboratory, Oak Ridge, Tennessee (Energy Systems 1996d). 
Before initiating site preparation work for the sluicing and pumping project, Lockheed Martin Energy Systems, Inc. (Energy Systems) evaluated the condition of the tanks to determine whether the stresses imposed by the site work and the sluicing could be sustained by the tanks without collapse and release of the contents. The evaluation included the following aspects:

- video inspection of interior of tanks (January 1996),

- $\quad$ structural analysis using the methodology outlined in "A Method for Evaluating the Structural Integrity of Buried Liquid Low-Level Waste Tanks" (Kincaid 1993) and a computer-aided finite element program (ABAQUS Version 5.5), and

- measurement of coupons cut from tanks during installation of new risers (September 1996).

The results of the analyses are reported in the Preliminary Engineering Report, Old Hydrofracture Facility Tanks Content Removal Project (Energy Systems 1996c), and Structural. Integrity Assessment for Installation of Tank Risers at the Old Hydrofracture Tanks (STEP 1996). The conclusion drawn from the evaluation was that the likelihood of tank rupture is highly unlikely. 


\section{SITE DESCRIPTION AND ENVIRONMENTAL SETTING}

The OHF is located on the Oak Ridge Reservation approximately $1 / 2$ mile south of WAG 1 (Fig. 2.1). Access to this area is restricted from the general public.

\subsection{TANKS DESCRIPTION}

The five OHF tanks are buried underground, approximately $110 \mathrm{ft}$ west of Building 7852 and approximately 131 yd east of White Oak Creek. The tanks lie parallel to each other in a north/south orientation (Fig. 2.2).

Tanks T-1 and T-2 are 15,000-gal tanks, measuring $8 \mathrm{ft}$ in diameter and $44.1 \mathrm{ft}$ in length. Tank T-9 is a 13,000 -gal tank, measuring $10 \mathrm{ft}$ in diameter and $42.3 \mathrm{ft}$ in length. Tanks T-3 and T-4 are 25,000 -gal tanks, measuring $10.5 \mathrm{ft}$ in diameter and $23.8 \mathrm{ft}$ in length. None of the tanks is currently full. Table 2.1 shows the current volume of liquid and sludge in each tank, compared to its capacity.

Table 2.1. Current tank contents

\begin{tabular}{ccccc}
\hline Tank & $\begin{array}{c}\text { Current liquid } \\
\text { volume } \\
\text { (gal) }\end{array}$ & $\begin{array}{c}\text { Current sludge } \\
\text { volume } \\
\text { (gal) }\end{array}$ & $\begin{array}{c}\text { Current total } \\
\text { volume } \\
\text { (gal) }\end{array}$ & $\begin{array}{c}\text { Capacity } \\
\text { (gal) }\end{array}$ \\
\hline T-1 & 10,780 & 1,407 & 12,187 & 15,000 \\
T-2 & 10,631 & 1,556 & 12,187 & 15,000 \\
T-9 & 4,929 & 1,141 & 6,070 & 13,000 \\
T-3 & 1,962 & 3,115 & 5,077 & 25,000 \\
T-4 & 14,789 & 2,309 & 17,098 & 25,000 \\
\hline
\end{tabular}

The OHF tanks were installed at the facility in two stages. Tanks T-1, T-2, and T-9, which are made of carbon steel and unlined, were installed as part of the original OHF construction, circa 1963. Tanks T-3 and T-4, which are rubber-lined carbon steel, were added in 1966. All five of the tanks were previously used elsewhere on the Oak Ridge Reservation and were refitted for use in the OHF system.

Tanks T-1, T-2, and T-9 are buried together in a single pit. Four-ft-high, 8-in.-thick concrete block walls separate the pit into three cells, one for each tank. Each cell is drained separately through a 6-in. perforated vitreous clay pipe into a 12-in. dry well. Each dry well has a (non-perforated) 6-in. vitreous clay outlet pipe that exits the well approximately $2 \mathrm{ft}$ above the bottom of the excavation and extends south to the slope north of the facility access road. The outlets for the T-1 and T-2 dry wells are enclosed together in an uncovered concrete box on the slope. The outlet for the T-9 dry well is enclosed in a separate concrete box. 


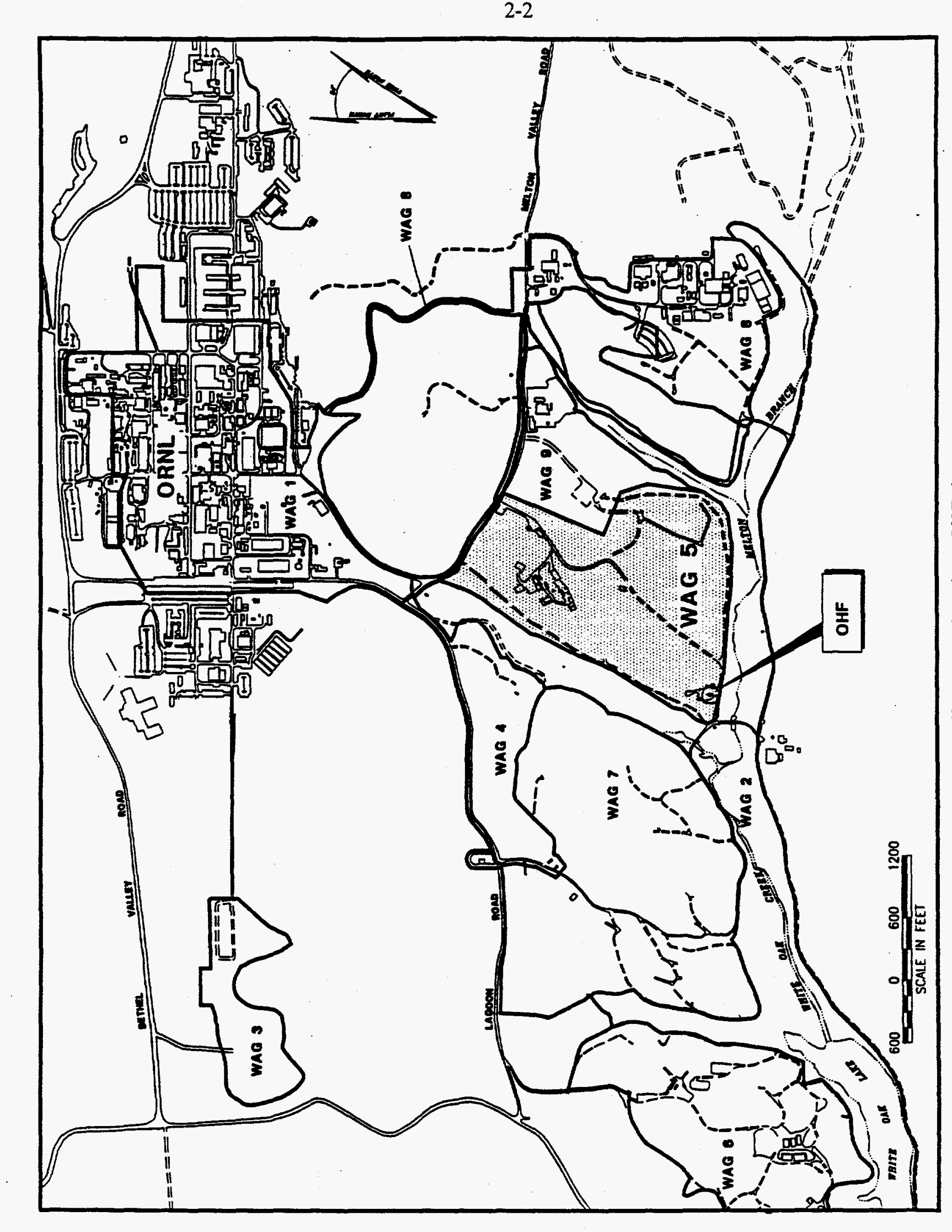



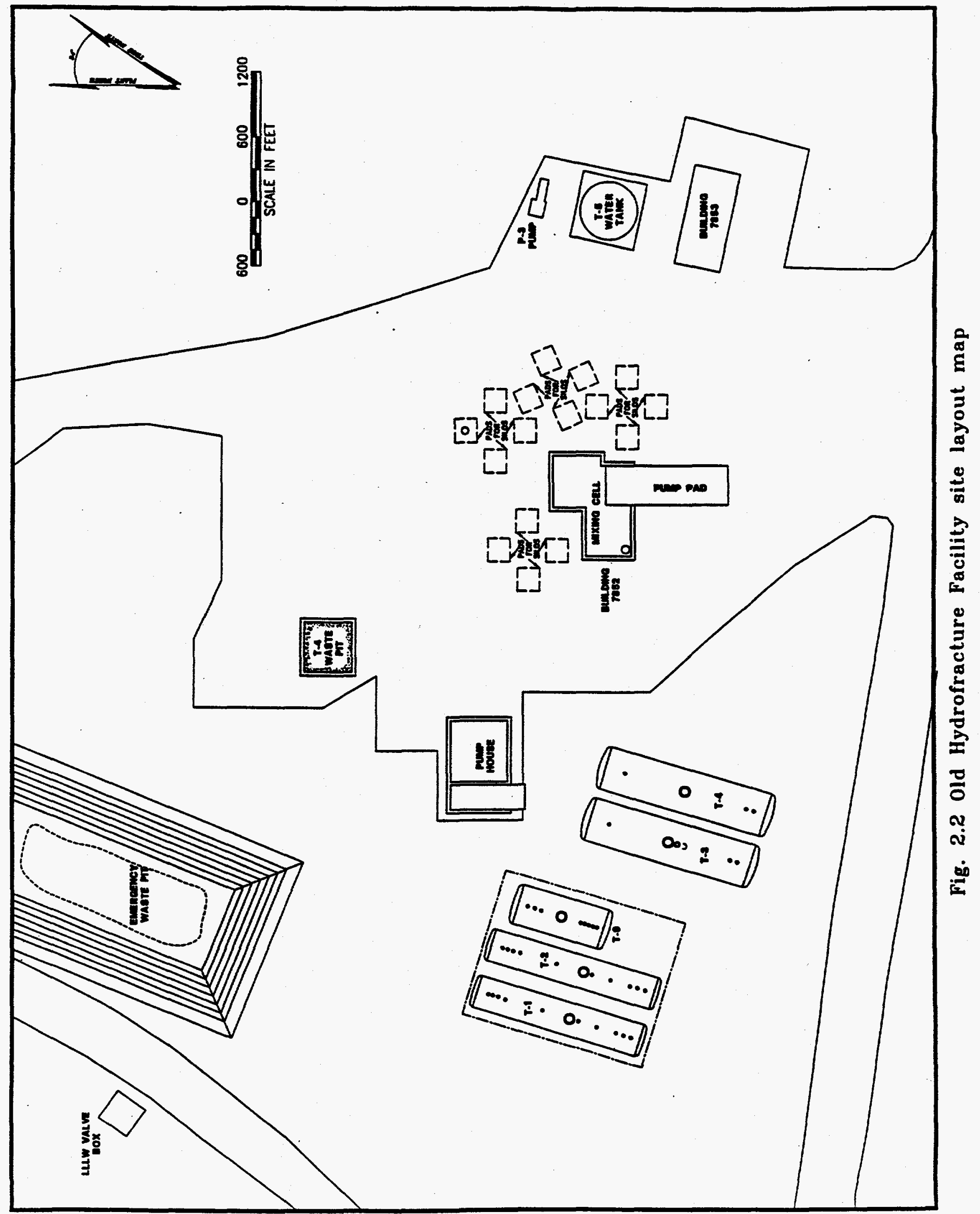
Figure 2.3 provides a plan view of the five tanks. ${ }^{1}$ Tanks T-3 and T-4 are buried together in a second pit. A 4-in. perforated vitreous clay pipe laid between the two tanks drains the pit into a 12-in. dry well. A 4-in. outlet pipe exits the well approximately $2 \mathrm{ft}$ above the bottom of the excavation. Anecdotal information suggests that this pipe is connected to the outlet for Tank T-9, upslope of the concrete box that encloses the end of the pipe. However, drawings confirming this piping arrangement have not been located. The concrete box designated "Box $A$ " in the figure contains the outlet pipes for $T-1$ and $T-2$. The box designated "Box B" contains the pipe into which the T-9 and possibly the T-3/T-4 outlets are connected.

Following installation of the tanks, each excavation pit was filled with between 5 and $6 \mathrm{ft}$ of 1-in. gravel (tanks T-1, T-2, and T-9 pit) or crushed stone (tanks T-3 and T-4 pit). A 6-mil polyethylene plastic sheet was placed over the gravel or stone and a minimum of $4 \mathrm{ft}$ of fill dirt was used to bring each pit to the finished grade. Figure 2.4 shows a vertical section of the backfilled tank pits. Figures 2.5 and 2.6 present details of the tank drainage systems, highlighting the elevations of the drainage pipes and well outlet pipes. ${ }^{1}$

\subsection{SURFACE WATER HYDROLOGY}

The OHF is located on a surface drainage divide separating the White Oak Creek Basin and the Melton Branch Basin. As shown in Fig. 2.7, surface water runoff from the ground surface above the tanks flows into both White Oak Creek and Melton Branch, the primary tributary to White Oak Creek. From White Oak Creek, surface water flows into White Oak Lake and, ultimately, the Clinch River.

As described in Sect. 2.1, the outlet pipes from the tank dry wells exit the ground just north of the facility access road, approximately $230 \mathrm{ft}$ from Melton Branch. Any liquid collecting in the tank drainage beds above the elevation of the outlet pipes (approximately $2 \mathrm{ft}$ above the bottom of the excavations), would be expected to flow through the outlet pipes, into the drainage ditch beside the access road, and toward both Melton Branch and White Oak Creek.

\subsection{GROUNDWATER HYDROLOGY}

The Conceptual Site Model for Risk Assessment for the OHF Tanks (Energy Systems 1996b) describes the subsurface hydraulic setting for the tanks. As described in that document and as illustrated in Fig. 2.8, the OHF tanks are located in the unsaturated zone, 5-6 ft above the water table. Liquids discharged from the tank drainage beds to the subsurface would be transported either horizontally through the shallow subsurface to Melton Branch, or vertically to the saturated zone. Groundwater flow at the OHF is southeast toward Melton Branch. In evaluating the contaminant flow through the saturated zone, the conceptual model assumes a hydraulic gradient of 0.01 and a hydraulic conductivity of $5.0 \times 10^{-5} \mathrm{~cm} / \mathrm{second}$.

\footnotetext{
${ }^{1}$ The figures presented in this section are based on engineering drawings E-004-D (1963) and EE-042-D (1966), prepared before construction. No as-built drawings verifying the dry well system layout have been located.
} 


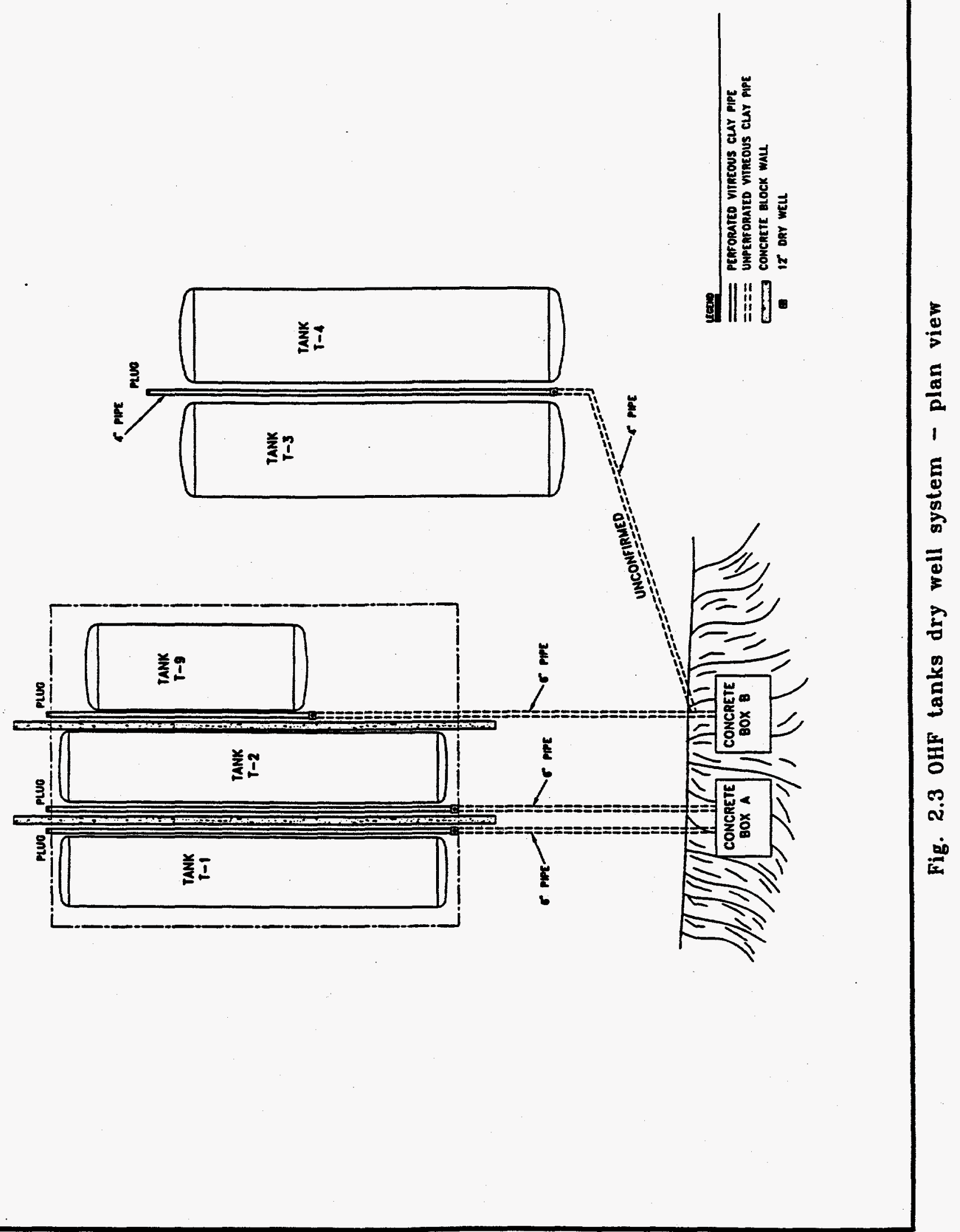


2-6

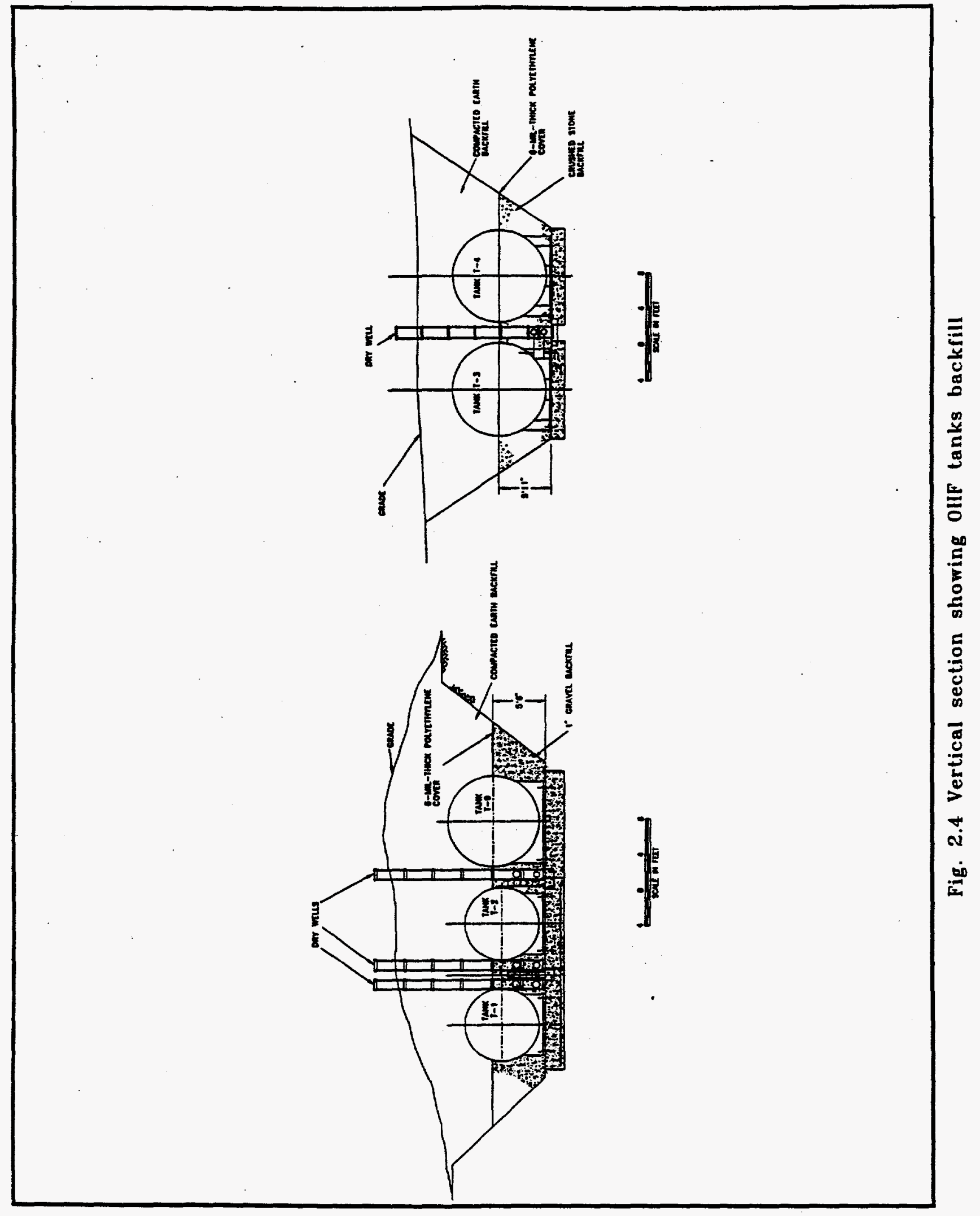


2-7

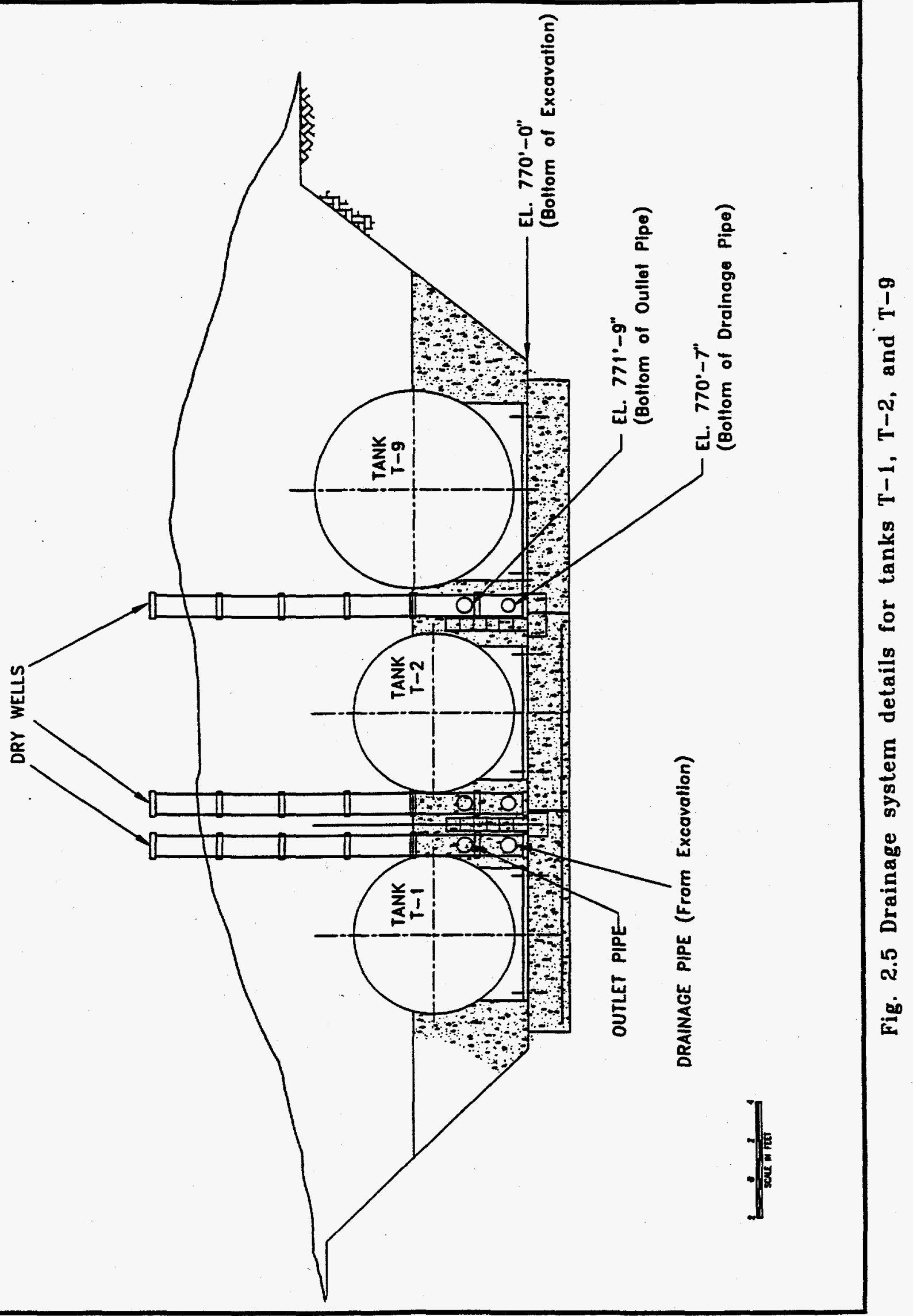




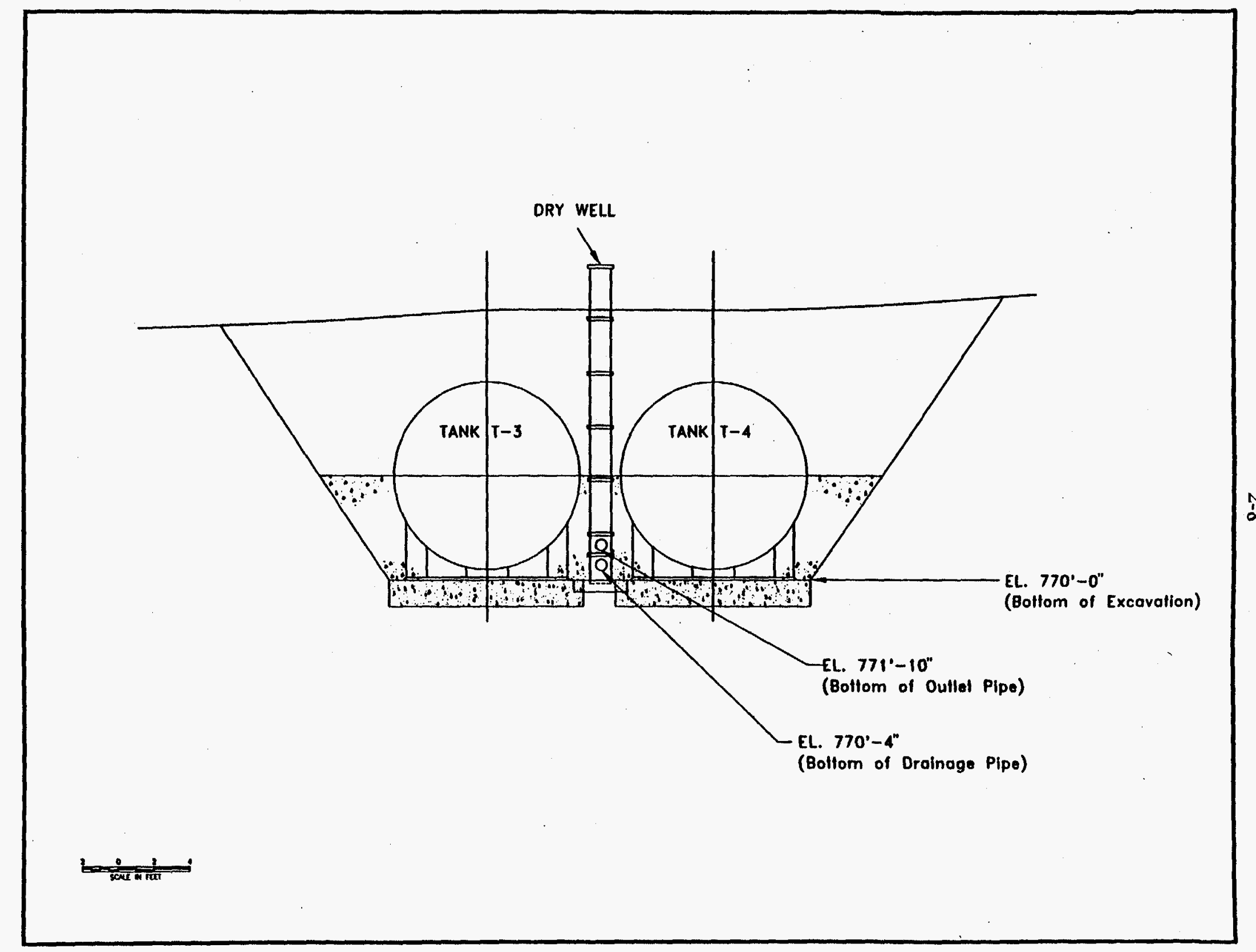

Fig. 2.6 Drainage system details for tanks $\mathrm{T}-3$ and $\mathrm{T}-4$ 


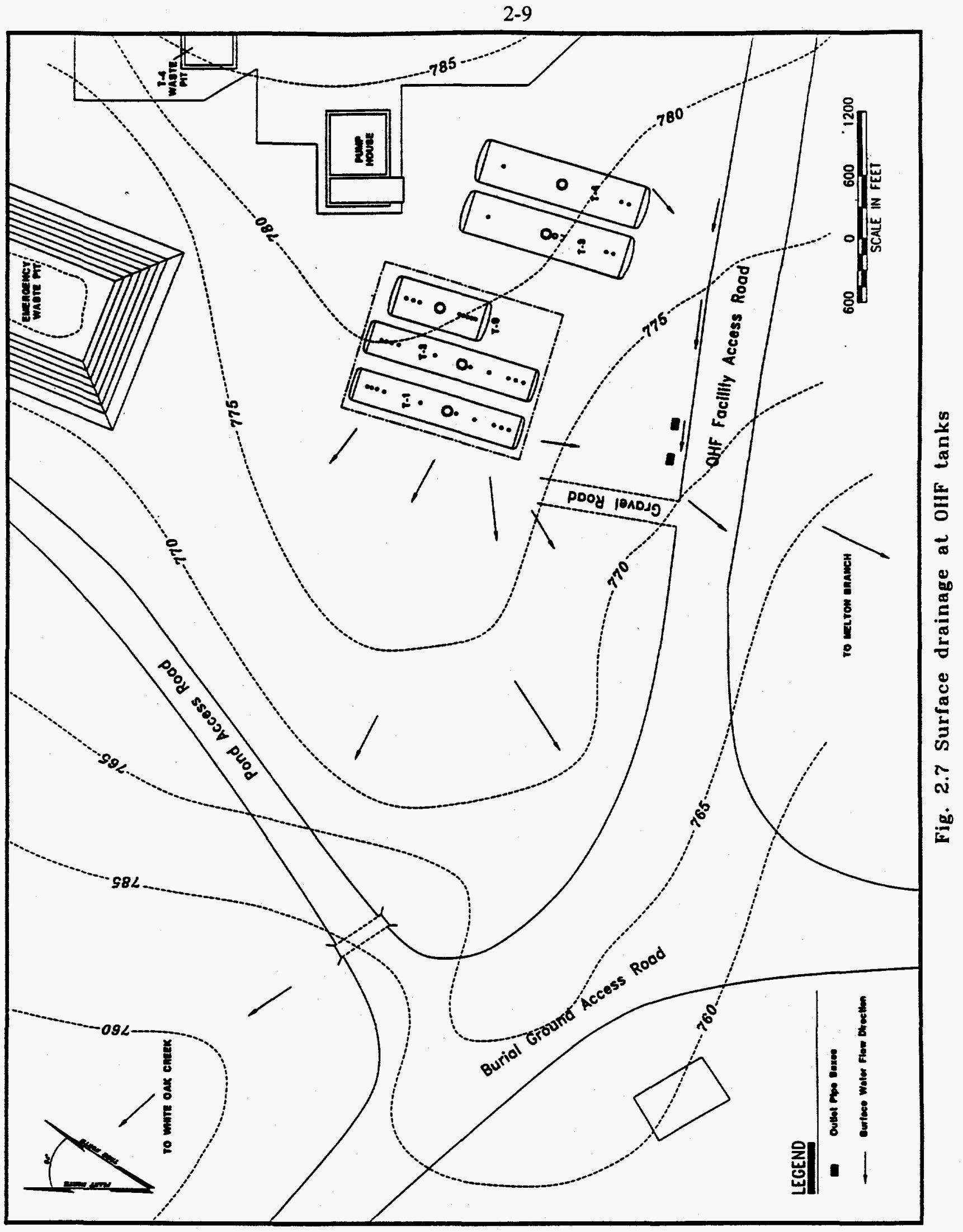



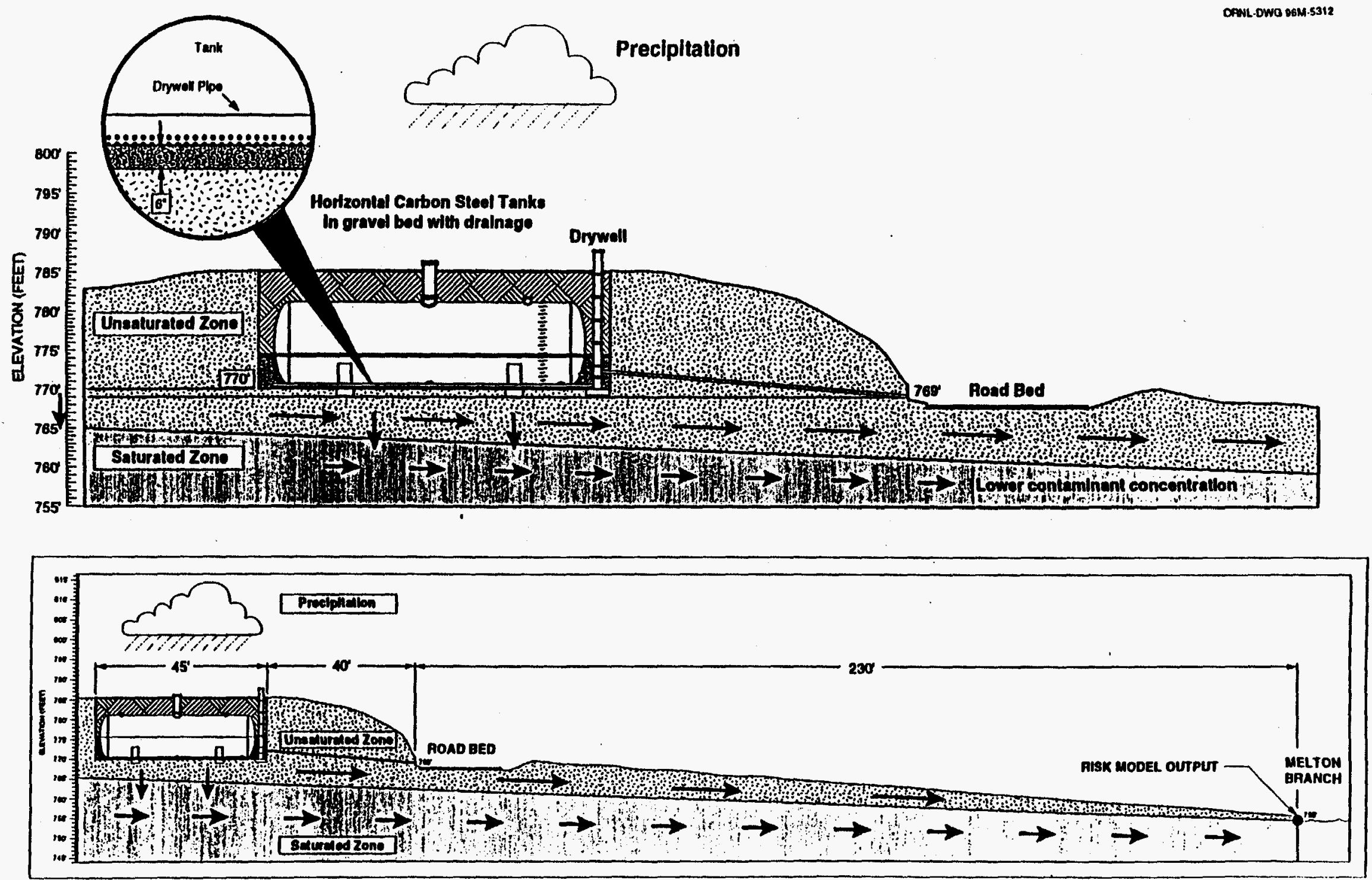

Fig. 2.8 Groundwater flow at OHF tanks 


\section{SLUICING SYSTEM}

The tank contents will be removed by resuspending the sludge in process water or supernatant, referred to as "sluice water," into a slurry and pumping it to the MVST. Resuspension of the sludge will be accomplished by spraying process water or supernatant into the tank, referred to as the "sluice tank," pumping it out to a recycle tank (tank T-9), and recirculating it through the sluice and recycle tanks by spraying and pumping. When the average solids content of the supernatant approaches $10 \%$, which is the maximum allowable, recirculation will be halted and the sluice water will be pumped to the MVST. The tanks will be cleaned one at a time in the following order: T-3 and T-9 combined, T-4, T-1, and T-2.

The total volume of supernatant in the five tanks exceeds the amount need to sluice the tanks. Table 3.1 compares the amounts of supernatant currently in each tank with the amounts required to sluice each tank. As shown in the table, all tanks have excess supernatant, with the exception of tank T-3. Before sluicing Tanks T-3 and T-9, supernatant will be transferred from tanks $T-1$ (3600 gal) and T-2 (3600 gal) to T-9. [See Section 5 of the Operations Plan (ORNL/ER-433)].

Table 3.1. Tank contents and supernatant requirements

\begin{tabular}{cccccc}
\hline Tank & $\begin{array}{c}\text { Sludge volume } \\
\text { (gal) }\end{array}$ & $\begin{array}{c}\text { Current } \\
\text { supernatant } \\
\text { (gal) }\end{array}$ & $\begin{array}{c}\text { Supernatant } \\
\text { required for } \\
\text { sluicing (gal) }\end{array}$ & $\begin{array}{c}\text { Supematant at } \\
\text { start of T-3/T-9 } \\
\text { siuicing } \\
\text { (gal) }\end{array}$ & $\begin{array}{c}\text { Supernatant at } \\
\text { start of T-4 } \\
\text { sluicing } \\
\text { (gal) }^{b}\end{array}$ \\
\hline T-1 & 1,410 & 10,780 & 5,290 & 5,290 & 5,290 \\
$T-2$ & 1,560 & 10,630 & 5,850 & 7,030 & 5,850 \\
T-3 & 3,120 & 1,960 & 11,700 & 1,960 & 7,310 \\
$T-4$ & 2,310 & 14,790 & 8,660 & 14,790 & 8,660 \\
$T-9$ & 1,140 & 4,930 & 4,280 & 14,020 & 0 \\
\hline
\end{tabular}

'Tanks T-3 and T-9 will be sluiced together, after transferring supernatant from tanks T-1 and T-2 to tank T-9. ${ }^{b}$ After tank T-3 is emptied, it will be used to store excess supernatant from tank T-2 and T-4. Tank T-4 will be sluiced next.

The sluicing system that will be used at OHF consists of the following: (1) a spray nozzle designated "the Borehole Miner," provided by the DOE EM-50 program, with an associated pump; (2) in-tank submersible pumps to transfer tank contents from the sluice tanks to the recycle tank;

(3) high-pressure pumps providing slurry circulation and slurry transport to the MVST; (4) piping;

(5) a ventilation system; (6) a process water system; (7) an instrumentation and control system centered around a programmable logic controller (PLC); (8) a video monitoring system; and (9) auxiliary equipment. Critical operating parameters are monitored at the operator machine interface, which is programmed to alert the system operator to certain conditions (e.g., pump shutdown, high or low pressure in the pumping system, etc.). A process flow diagram, reprinted from Old Hydrofracture Facility Tanks Contents Removal Action Operations Plan at the Oak Ridge National Laboratory, Oak Ridge, Tennessee (Bechtel Jacobs Company LLC 1998), is presented as Fig. 3.1. 


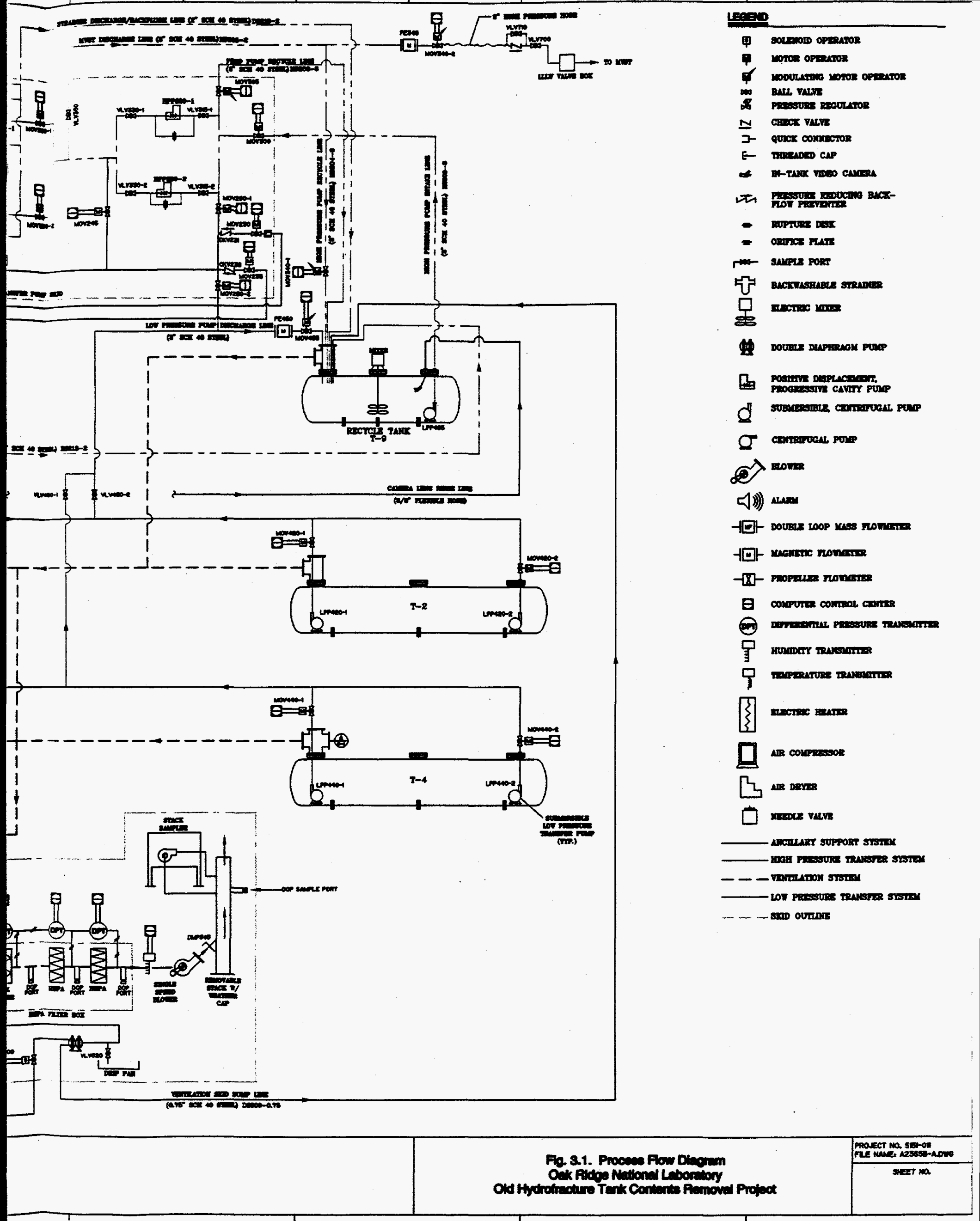


The Old Hydrofracture Facility Tanks Contents Removal Action Operations Plan at the Oak Ridge National Laboratory, Oak Ridge, Tennessee (Bechtel Jacobs Company LLC 1998) describes the operations of each piece of equipment in the sluicing system, includes work instructions for each step of the sluicing process, and includes checklists to be used when inspecting the system before operations begin and when sluicing operations for a given day are complete. Before being assembled at the OHF site, the sluicing system was thoroughly tested at the ORNL Robotics and Process Systems Complex and will be dismantled and reassembled at the OHF site. System operators were trained to operate the equipment during the test process. 


\section{RELEASE SCENARIOS}

This contingency plan evaluates a series of possible environmental release scenarios that have been identified for the OHF tank sluicing project. Eight scenarios previously identified in the earlier version of the plan have been reevaluated and reconsolidated into three scenarios. A fourth scenario related to Borehole Miner failure has been added.

After the publication of the earlier version of this plan in October 1996, an additional round of tank samples were analyzed and it was determined that isotopic dilution of the waste would eliminate any concern about criticality. The results of the analyses appear in Characterization of the Old Hydrofracture (OHF) Waste Tanks Located at ORNL (Keller, Giaquinto, and Meeks 1997). As described in the Work Plan for Denaturing Waste in the OHF Tanks (Energy Systems 1998), depleted uranium in the form of a uranyl nitrate solution will be added to the contents of each tank before sluicing begins, ensuring the waste meets the requirements MVST waste acceptance criteria for subcriticality. See Waste Acceptance Criteria for Liquid Low-Level Waste System, Process Waste Treatment Complex-Building 3544, and Process Waste Treatment Complex-Building 3608 (WM-LWS-WAC).

Section 4.1 provides an overview of the scenarios. Sections 4.2 through 4.5 discuss the possible causes, likelihood of occurrence, release mechanisms, exposure pathways, and release potential of each.

\subsection{OVERVIEW OF RELEASE SCENARIOS}

Three basic release scenarios have been identified for the OHF tank sluicing project, as follows:

1. underground tank release,

2. aboveground release,

3. ventilation system failure, and

4. Borehole Miner arm retraction failure.

Table 4.1 lists each of the release scenarios, along with the possible causes, likelihood of occurrence, indicators of event occurrence, potential exposure pathways, and potential release volumes.

\subsection{UNDERGROUND RELEASE}

Two types of underground liquid release were identified - tank rupture, which could result in total or near total release of tank contents, and tank leak, which could result in partial release of tank contents. As shown in Table 4.1, the underground release scenario poses the risk for the largest release, 20,240 gal. The Conceptual Site Model for Risk Assessment for the OHF Tanks (Energy Systems 1996b) estimated the risk posed by leakage of the contents of all five tanks to be less than $1 \times 10^{-4}$ at the Melton Branch seep face. 
Table 4.1. Sluicing project release scenario matrix

\begin{tabular}{|c|c|c|c|c|c|}
\hline Release & Possible causes & $\begin{array}{l}\text { Likelihood of } \\
\text { occurrence }\end{array}$ & Indicator & Release pathway & $\begin{array}{c}\text { Release } \\
\text { potential }\end{array}$ \\
\hline \multirow{8}{*}{$\begin{array}{l}\text { Underground release (tank } \\
\text { leak or rupture) }\end{array}$} & Earth fill load & Extremely low & \multirow{8}{*}{$\begin{array}{l}\text { Alarm indicates increase } \\
\text { in radioactivity in dry } \\
\text { well } \\
\text { Unexpected drop in tank } \\
\text { liquid levels (video } \\
\text { observation or bubbler } \\
\text { readings) }\end{array}$} & \multirow{8}{*}{$\begin{array}{l}\text { Subsurface } \\
\text { contamination }\end{array}$} & \multirow{8}{*}{$\begin{array}{l}15,160 \mathrm{gal}^{a} \\
52,600 \mathrm{gal}^{b}\end{array}$} \\
\hline & Earthquake & Improbable & & & \\
\hline & Equipment dropped on tank & Low & & & \\
\hline & Flood & Low & & & \\
\hline & Sluice jet pressure & Extremely low & & & \\
\hline & Sluicer installation or shift & Low & & & \\
\hline & Heavy equipment load & Low & & & \\
\hline & Current undetected leak & Low & & & \\
\hline \multirow{6}{*}{$\begin{array}{l}\text { 2. Aboveground release (leak, } \\
\text { rupture or spill from } \\
\text { sluicing system) }\end{array}$} & $\begin{array}{l}\text { Improper equipment installation or } \\
\text { equipment flaw }\end{array}$ & Low & \multirow{6}{*}{$\begin{array}{l}\text { Visual observation } \\
\begin{array}{l}\text { Alarm indicates loss of } \\
\text { pressure }\end{array} \\
\begin{array}{l}\text { Accumulation of liquid in } \\
\text { pump skid or sluicer skid } \\
\text { drip pan }\end{array}\end{array}$} & \multirow[t]{6}{*}{$\begin{array}{l}\text { Surface contamination } \\
\text { Air dispersion }\end{array}$} & \multirow[t]{6}{*}{$20,240 \mathrm{gal}^{c}$} \\
\hline & Vehicle accident & Low & & & \\
\hline & Flange failure & Low & & & \\
\hline & Earthquake & Improbable & & & \\
\hline & High wind, lightening & Low & & & \\
\hline & Spill & Low & & & \\
\hline \multirow[t]{2}{*}{ 3. Ventilation system failure } & Fan shutdown & Low & \multirow[t]{2}{*}{ Alarm } & \multirow[t]{2}{*}{ Air dispersion } & \multirow[t]{2}{*}{ Not calculated } \\
\hline & HEPA filter breakthrough & Low & & & \\
\hline 4. Borehole Miner failure & Arm does not retract & Moderate & Visual observation & Air dispersion & Not calculated \\
\hline
\end{tabular}

"Tank T-9 contents (after addition of supernatant for sluicing Tank T-3).

${ }^{\text {b }}$ Combined volume of all five tanks.

${ }^{\circ}$ Expected combined volumes of tanks T-3 and T-9, immediately before sluicing (after transfer of supernatant from tanks $\mathrm{T}-1$ and $\mathrm{T}-2$ ).

ND - Not determined 


\subsubsection{Tank Rupture}

For purposes of this report, a tank rupture is a breach in the tank wall that causes total loss of the tank contents to the subsurface. Possible causes of a tank rupture include the pressure of the earth fill above the tank, an earthquake, impact from equipment dropped on tank riser, hydrostatic pressure from flooding, the pressure of the sluice jet or impact of sluicer against tank wall, and load increases due to any of the following: hoisting and securing the sluicer on each tank, shifting of the sluicer, and placement of heavy equipment on the ground surface above a tank.

As noted in Sect. 1.2, evaluations of the structural integrity of the tanks indicate that tank rupture is highly unlikely. Based on the measurements of tank coupons cut during installation of the new risers, the tanks appear to have retained sufficient wall thickness to support the loads projected to be imposed during the sluicing project. However, the significant release potential of the tanks warrants contingency planning for the rupture scenario.

The structural analyses performed on tank integrity did not evaluate the impact of an earthquake on tank integrity. The likelihood of an earthquake occurring during the sluicing project is considered to be improbable and the contingency strategy presented later in Sect. 5 does not plan for that scenario. Both the Preliminary Engineering Report, Old Hydrofracture Facility Tanks Content Removal Project (Energy Systems 1996c) and the Basis for Interim Operation, Facility 7852, Old Hydrofracture Facility (Energy Systems 1996a) discuss the earthquake potential and support the approach taken here.

Assuming the preventive measures described in Sect. 5 are followed, the sole potential exposure pathway for tank rupture is subsurface contamination. The release potential ranges from $6,070 \mathrm{gal}$, the current volume of tank T-4 to $52,619 \mathrm{gal}$, the combined contents of all five tanks.

\subsubsection{Tank Leak}

A localized breach of a tank wall is considered a tank leak for purposes of this document, as opposed to a tank rupture, which is considered total failure of the tank wall as a containment system. The possible cause of a tank leak, as noted in Table 4.1 , is leaking through currently undetected breaches in the tank walls. If breaches in the tank walls exist but are plugged with precipitated material, the plugs may dissolve during sluicing and begin leaking.

Because none of the tanks are known to be leaking at this time, this document only addresses the risk of leakage during the sluicing operation on each tank and assumes that a maximum of two tanks would leak simultaneously - the tank undergoing sluicing (sluice tank) and the recycle tank, T-9. The release potential ranges from 6,070 gal for leakage from tank T-9 to 20,240 gal for simultaneous leakage from T-9 and T-3. The release pathway is through subsurface contamination.

\subsection{ABOVEGROUND LIQUID RELEASE}

Several of the release scenarios pose the risk of a tank slurry release to the ground surface. These scenarios include a leak or rupture of the waste transfer pipeline or aboveground sluicing equipment, and a spill from any piece of portable or removable equipment. Each scenario is discussed briefly below. 


\subsubsection{Waste Transfer Pipeline Rupture or Leak}

The sluiced tank contents will be transported to the MVST via a temporary transfer lane running approximately $140 \mathrm{ft}$ from the sluice project pump trailer to an existing valve box, and then through a segment of existing pipeline that runs between the active LLLW system evaporator tanks and the MVST. Possible causes of a leak in the transfer line include a defect in or improper installation of the equipment, a vehicular accident, earthquake, high winds, or a lightning strike.

The new pipeline consists of 2-in.-diameter, reinforced hose. It will be installed aboveground. The low point of the line will be just inside the valve box. As noted in Table 4.1, the estimated release potential is 20,240 gal, which is the volume projected to be transferred from tanks $T-3$ and T-9, which will be sluiced together [see Section 5 of the Operations Plan (ORNL/ER-433 Bechtel Jacobs Company LLC 1998)].

\subsubsection{Leak from Operating Sluice Equipment}

System leaks are most likely to occur at the numerous flanges and nipples which connect the system components (e.g., instruments, pipes, etc.) together. In addition, an earthquake, high winds, lightening, a vehicular accident, or the impact of equipment dropped on the system could cause a rupture or leak.

The impact of a leak in the sluice system depends on whether the leak occurs in a suction line or a discharge line. A leak in a suction line would likely drip, whereas a leak in a discharge line would likely spray. The greatest release potential for this scenario is 20,240 gal (Table 4.1), which assumes catastrophic rupture of the lines and loss of the entire contents of tanks T-3 and T-9, which will be sluiced together.

\subsubsection{Spill from Sluice Equipment During Maintenance or Transfer Between Tanks}

The sluice system used for the OHF tanks will be a portable system that will be used to sluice one tank at a time. Upon completion of sluicing at one tank, the sluice equipment will be removed by operating personnel and installed in the next tank. In addition, maintenance may be performed on the system during the course of the sluicing project. While procedures will be developed for flushing and draining the lines, there is a possibility of spilling tank contents while transferring the equipment. The release potential for this scenario is approximately 65 gal, which assumes the entire capacity of the portable pipelines is spilled.

\subsection{VENTILATION SYSTEM FAILURE}

During sluicing and denaturing operations at OHF, the tanks will be ventilated and off-gases treated with a high-efficiency particulate air (HEPA) filter before atmospheric discharge. Two types of failure in this system could result in unfiltered air from the tanks being discharged to the atmosphere.

During certain valve alignments, a shutdown of the ventilation system fan would result in a direct discharge of off-gases to the atmosphere. Likely causes of fan shutdown include inadvertent shutdown, power failure, and breakage of the fan belt. 
A failure of the HEPA filter would result in reduced filter performance and possibly the discharge of contaminants to the atmosphere. Filter failure could result from excessive moisture loading or a filter puncture. Excessive moisture loading would be characterized by an increase in the differential pressure across the filter.

\subsection{BOREHOLE MINER FAILURE}

The Borehole Miner, manufactured by Waterjet Technology, Inc., consists of a 30-ft$(9.1-\mathrm{m}-)$ long mast from which an arm can be extended, rotated, and angled to direct a stream of liquid or slurry. The stream flows through the middle of the 10-ft (3-m) arm and discharges from a nozzle in the end of the arm. For use in underground storage tanks, a support stand (or bridge) was constructed and the Borehole Miner modified to operate from the bridge. The purpose of the Borehole Miner system is to direct and focus the flow of slurry that is being fed to it and to dislodge and suspend consolidated material in the bottom of the tanks. The Borehole Miner is not capable of increasing the flow or the pressure of the slurry feed.

The Borehole Miner arm retraction function has failed to operate properly on two occasions, necessitating repairs and some modification to the hose management system. A failure of the Borehole Miner retraction function during sluicing would mean that the mast would need to be removed from the tank with the arm fully extended. The result would be a greatly enhanced potential for site contamination. 


\section{CONTINGENCY STRATEGY}

This section describes measures that will be taken to minimize the risk of occurrence of the release scenarios discussed in Sect. 4 of this plan and to ensure that any release is detected as quickly as possible and the appropriate response is initiated. Preventive measures include design features of the sluicing and pumping equipment, as well as operating procedures designed for the project. Detection methods range from visual inspection to electronic sensors and alarm systems.

Table 5.1 presents a matrix identifying measures that should be taken when various indicators suggest possible releases.

\subsection{UNDERGROUND RELEASE}

While the causes of tank rupture and tank leak vary, the release mechanisms are similar; tank contents are released to the subsurface drainage bed that surrounds the buried tanks. Methods of preventing tank leaks and ruptures focus on evaluating the condition of the tanks before the start of the project to affirm the competence of the tanks to withstand the anticipated stresses. As discussed in Sect. 1, structural analyses have affirmed the integrity of the tanks. In addition, the placement of heavy equipment on the ground surface above the tanks will be prohibited. The perimeters of each tank will be roped off and signs posted to warn against heavy equipment placement.

A three-part monitoring program is proposed for detecting a tank leak or rupture. As noted in Sect. 4, it is assumed that the risk of a tank leak or rupture is likely only during sluicing, and that no more than two tanks at a time will be involved in sluicing (sluice tank and recycle tank). Each tank will be monitored for leaks/rupture during the time it is involved in sluicing.

The core of the leak/rupture detection program is an alarming radiation monitor that will be installed in the dry wells associated with the sluice and recycle tanks. The alarm will supply readings to the operator machine interface that will provide on-screen alarms if there is an increase in radioactivity in a dry well. It will be assumed that an increase in radioactivity indicates a leaking tank. A video monitor and level monitors in the tanks will supplement the well monitoring probe.

If an alarm indicates the possibility of a tank leak or rupture, sluicing will be stopped (per the emergency shutdown work instruction in the Operations Plan) and the tank liquid levels will be checked to provide confirmation. Sampling and field analysis of the well contents may be useful in determining whether a leak has occurred. If a tank is believed to be leaking, the remaining contents will be pumped out to another tank, the Facility Manager will be notified, and the situation will be evaluated to determine the best course of action.

\subsection{ABOVEGROUND RELEASE}

An aboveground release might occur as the result of a break or leak in the sluice system piping, pumps, or associated equipment; a break or leak in the waste transfer pipeline; or a spill 
Table 5.1. Contingency matrix

\begin{tabular}{|c|c|c|c|}
\hline Indicator & Probable Cause & $\begin{array}{l}\text { Release } \\
\text { Category }\end{array}$ & Response \\
\hline $\begin{array}{l}\text { Alarm indicates increase in } \\
\text { radioactivity in dry well } \\
\text { Video observation or bubbler } \\
\text { indication of unexpected liquid } \\
\text { level drop in sluice or recycle tank }\end{array}$ & $\begin{array}{l}\text { Tank rupture or } \\
\text { leak }\end{array}$ & $\begin{array}{l}\text { Underground } \\
\text { release }\end{array}$ & $\begin{array}{l}\text { Check liquid level in tank. If } \\
\text { dropping: (1) stop sluicing, (2) } \\
\text { transfer remaining tank contents to } \\
\text { another tank, (3) notify Facility } \\
\text { Manager, and (4) evaluate situation. }\end{array}$ \\
\hline $\begin{array}{l}\text { Alarm indicates presence of liquid } \\
\text { in pump or sluicer skid drip pan or } \\
\text { in riser boxes } \\
\text { Visual observation of leak or } \\
\text { rupture }\end{array}$ & $\begin{array}{l}\text { Pipe or pump } \\
\text { leak }\end{array}$ & $\begin{array}{l}\text { Aboveground } \\
\text { release }\end{array}$ & $\begin{array}{l}\text { Check visually for presence of liquid } \\
\text { in drip pan or for leak. If liquid in } \\
\text { drip pan or riser box or leak is } \\
\text { detected: (1) stop sluicing, (2) drain } \\
\text { or pump drip pan liquid into recycle } \\
\text { tank, (3) notify Facility Manager, } \\
\text { and (4) repair leak. }\end{array}$ \\
\hline \multicolumn{4}{|l|}{$\begin{array}{l}\text { Alarm indicates loss of pressure in } \\
\text { sluice system }\end{array}$} \\
\hline Visual indication of spill & Spill & $\begin{array}{l}\text { Aboveground } \\
\text { release }\end{array}$ & $\begin{array}{l}\text { Stop sluicing, notify Facility } \\
\text { Manager, contain spill }\end{array}$ \\
\hline $\begin{array}{l}\text { Alarm indicates pressure increase in } \\
\text { ventilation system } \\
\text { Alarm indicates fan shutdown }\end{array}$ & $\begin{array}{l}\text { HEPA filter } \\
\text { failure } \\
\text { Belt wear } \\
\text { Power failure }\end{array}$ & $\begin{array}{l}\text { Ventilation } \\
\text { system failure }\end{array}$ & $\begin{array}{l}\text { Stop sluicing, align system valves to } \\
\text { minimize atmospheric release, notify } \\
\text { Facility Manager, check system for } \\
\text { excess moisture loading, repair } \\
\text { system }\end{array}$ \\
\hline
\end{tabular}

from any of the equipment during routine operations, tank contents denaturing, or maintenance activities.

If a leak is detected in the system, the system will be shut down (per the emergency shutdown work instruction), any spill will be contained and the Hazardous Waste Operations Group contacted for spill cleanup, and the system repaired. A spill control kit containing absorbent materials, shovels, a drum, and appropriate personal protective equipment will be maintained on-site.

\subsubsection{Sluice System Leak}

Several leak prevention features have been designed into the tank sluicing system to prevent aboveground leaks. First, the discharge pipe segments, through which supernatant flows from the low pressure pump into the recycle tank and from the recycle tank to the sluicer, will be doubly contained and equipped with pressure relief and pump cutoff systems. The pressure relief lines are designed to divert supernatant from the discharge (pressurized) lines to the suction lines if the pressure in the discharge lines increases above the set point of the rupture disks. The pump cutoff system will include high pressure and low pressure cut-off switches. If a discharge line becomes overly pressurized or the secondary (outer) pipe is breached, the pump will shut down automatically. Additionally, operators will be able to continuously monitor pressure in the pumps and to control pump operation from the control trailer.

Second, the suction lines drawing supernatant from the sluice tank to the recycle tank and from the recycle tank to the high pressure pump will be supported such that any leaking liquid would flow, via gravity, back into the tank. 
Third, the pump skid and sluicer skid are fully enclosed, with drip pans to contain leaks and double diaphragm pumps to pump any leaked material into the recycle tank. The PLC will monitor the sumps for the detection of liquid and alert the system operator.

Another feature designed to prevent leaks from the sluicing system is the use of flange guards on all flanges connecting the various equipment through which the supernatant will flow. These guards will prevent spraying from flange connections in the event of seal rupture. Finally, because all of the sluicing equipment will be installed aboveground, leaks may be detected visually by personnel in the area or on the video monitor in the control trailer.

\subsubsection{Waste Transfer Pipeline Leak}

The pipeline used to transfer the sluiced tank contents to the MVST valve box tie-in will be installed aboveground and will be a doubly contained system. It will consist of 2 -in.-diameter, reinforced hose. It will function as a gravity-flow system and the low-point will be just inside the valve box connection to the MVST pipeline. Any leaking liquid would be expected to flow back up into the pump skid sump and be pumped by the double diaphragm pump into the recycle tank.

\subsubsection{Spill from Sluicing Equipment}

Every effort will be made to avoid spilling waste and denaturing material, including placement of plastic under equipment when appropriate. If a spill does occur, a spill control kit containing absorbent materials, shovels, a drum, and appropriate personal protective equipment will be maintained on-site. Any spill will be maintained immediately.

\subsection{VENTILATION SYSTEM FAILURE}

To minimize the risk of ventilation fan shutdown, the ventilation system will be served by the backup generator and inspected at the beginning and at the end of each day that the sluicing system is operated. See the daily and post-operational checklists in the Operations Plan (ORNL/ER-433, Bechtel Jacobs Company LLC 1998). In the event of a fan failure, sluicing will be stopped and the ventilation operator will align system valves to minimize atmospheric release.

In the event of an increase in the differential pressure across the HEPA filter, the sluicing operation will be stopped and the system inspected for excessive moisture loading. Appropriate actions to assure proper HEPA filter operation will be taken before restart of the sluicing operation.

\subsection{BOREHOLE MINER FAILURE}

\subsubsection{Management of the Borehole Miner Hose}

A key to the extension and retraction of the borehole is management of the hose which extends from the mast. Its unrestricted movement should be arranged such that the arm can be extended and retracted the full nine feet. This entails ensuring the hose is not wound around any other equipment or piping. Special attention must be given to the hose when the mast is rotated $180^{\circ}$ to affect cleaning of the other end of the tank. On certain tanks, depending upon the surrounding equipment and length of hose necessary to reach the tank, there may not be enough 
hose to allow the nine-foot extension or would restrict retraction. This kind of operational limit will be established once the Borehole Miner is installed in the tank and the hose movement observed before the start of sluicing.

\subsubsection{Contingency Plan for the Borehole Miner}

In the event that the extendible arm of the Borehole Miner does not retract, the following steps would be performed. Before installation of the Borehole Miner in the center riser of the tank to be sluiced, a plastic sleeve will be placed around the riser. This sleeve will be of sufficient length such that it would cover the entire length of the extendible arm. If the arm cannot be retracted, the mast will be pulled out of the tank riser with the arm in the relaxed position. As it is pulled out, the sleeve will be tied or taped off on the mast. The sleeve will be extended over the entire length of the mast and arm as it is being pulled from the tank. It will be tied or taped closed once the end of the extendible arm has been pulled out of the tank riser. This will help contain radioactive contamination.

\subsection{REPORTING REQUIREMENTS}

The Facility Manager should be notified if there is a release of tank contents or unfiltered air from the tanks to the environment. The Facility Manager will report any occurrence, following procedure OP-301, "Occurrence Notification and Reporting." 


\section{REFERENCES}

Bechtel Jacobs Company LLC 1998. Old Hydrofracture Facility Tanks Contents Removal Action Operations Plan at the Oak Ridge National Laboratory, Oak Ridge, Tennessee. ORNL/ER-433.

CDM Federal (CDM Federal Program Corporation) 1997. Oak Ridge National Laboratory, Old Hydrofracture Facility Tanks Contents Removal Project 100\% Configuration. Document Control No. 5151-011-DS-BBLS.

DOE (U.S. Department of Energy) 1994. U.S. Department of Energy, Radiological Control Manual. DOE/EH-0256T, Revision 1, April.

Energy Systems (Martin Marietta Energy Systems, Inc.) 1994. X-10 Site Emergency Plan. ORNL/CF-91/71/R2, September.

Energy Systems (Lockheed Martin Energy Systems, Inc.) 1996a. Basis for Interim Operation, Facility 7852, Old Hydrofracture Facility. ORNL/BIO/7852/ER/R1.

Energy Systems (Lockheed Martin Energy Systems, Inc.) 1996b. Conceptual Site Model for Risk Assessment for the OHF Tanks. ORNL-DWG 96M-5312.

Energy Systems (Lockheed Martin Energy Systems, Inc.) 1996c. Preliminary Engineering Report, Old Hydrofracture Facility, Tanks Content Removal Project. ORNL/ER-372.

Energy Systems (Lockheed Martin Energy Systems, Inc.) 1996d. Site Characterization Summary Report for the Old Hydrofracture Facility, Waste Area Grouping 5, at Oak Ridge National Laboratory, Oak Ridge, Tennessee. ORNL/ER-360.

Energy Systems (Lockheed Martin Energy Systems, Inc.) 1997. Site-Specific Health and Safety Plan for the Old Hydrofracture Facility Tanks Contents Removal Project at Oak Ridge National Laboratory, Oak Ridge, Tennessee. ORNL/ER-427.

Energy Systems (Lockheed Martin Energy Systems, Inc.) 1998. "Work Plan for Denaturing Waste in the OHF Tanks." Engineering Transmittal XMTL No. PX092. January 30.

Kincaid, J.H., 1993. A Method for Evaluating the Structural Integrity of Buried Liquid Low-Level Waste Tanks. Presented at the 1993 Symposium on Waste Management of the American Nuclear Society.

STEP (Solutions to Environmental Problems, Inc.) 1996. Structural Integrity Assessment for Installation of Tank Risers at the Old Hydrofracture Tanks. 


\section{DISTRIBUTION}

1. J. F. Alexander (U)

2. C. A. Bednarz (U)

3. G. F. Boris (U)

4. D. G. Brown (U)

5. J. E. Francis (U)

6. J. A. Hoffmeister (U)

7. C. E. Mulkey (U)

8. P. T. Owen (U)

9. L. B. Raulston (U)

10. D. G. Rowland (U)

11. S. T. Rudell (U)

12. M. L. Whitehead

13. Central Research Library (U)

14. File-EMEF DMC (U)

15. File-EMEF DMC-RC

16. J. LaForest, CDM Federal Programs Corporation, 800 Oak Ridge Turnpike, Suite 500, Oak Ridge, TN 37830

17. D. McCurry, CDM Federal Programs Corporation, 800 Oak Ridge Turnpike, Suite 500, Oak Ridge, TN 37830 (U) 